\title{
Carbon Black Particle Exhibits Size Dependent Toxicity in Human Monocytes
}

\author{
Devashri Sahu, ${ }^{1}$ G. M. Kannan, ${ }^{1}$ and R. Vijayaraghavan ${ }^{2}$ \\ ${ }^{1}$ Pharmacology and Toxicology Division, Defence Research and Development Establishment, Jhansi Road, Gwalior 474002, India \\ ${ }^{2}$ Saveetha University, P.H. Road, Chennai 600077, India \\ Correspondence should be addressed to Devashri Sahu; devashree.sahu@gmail.com
}

Received 12 September 2013; Revised 22 November 2013; Accepted 1 December 2013; Published 5 February 2014

Academic Editor: Irfan Rahman

Copyright (c) 2014 Devashri Sahu et al. This is an open access article distributed under the Creative Commons Attribution License, which permits unrestricted use, distribution, and reproduction in any medium, provided the original work is properly cited.

\begin{abstract}
Increased levels of particulate air pollution are associated with increased respiratory and cardiovascular mortality and morbidity. Some epidemiologic and toxicological researches suggest ultrafine particles $(<100 \mathrm{~nm})$ to be more harmful per unit mass than larger particles. In the present study, the effect of particle size (nano and micro) of carbon black (CB) particle on viability, phagocytosis, cytokine induction, and DNA damage in human monocytes, THP-1 cells, was analysed. The cells were incubated with nanosize $(\sim 50 \mathrm{~nm})$ and micron $(\sim 500 \mathrm{~nm})$ size of CB particles in a concentration range of $50-800 \mu \mathrm{g} / \mathrm{mL}$. The parameters like MTT assay, phagocytosis assay, ELISA, gene expression, and DNA analysis were studied. Exposure to nano- and micron-sized CB particles showed size- and concentration dependent decrease in cell viability and significant increase in proinflammatory cytokines IL-1 $\beta$, TNF- $\alpha$ and IL- 6 as well as chemokine IL- 8 release. Gene expression study showed upregulation of monocyte chemoattractant protein-1 gene while cyclooxygenase-2 gene remained unaffected. Nano CB particles altered the phagocytic capacity of monocytes although micron $\mathrm{CB}$ had no significant effect. CB particles did not show any significant effect on DNA of monocytes. The investigations indicate that $\mathrm{CB}$ particles in nanosize exhibit higher propensity of inducing cytotoxicity, inflammation, and altered phagocytosis in human monocytes than their micron size.
\end{abstract}

\section{Introduction}

The nanoparticle industry has expanded substantially in recent years leading to exposure of various nanomaterials to human and environment. Particle size plays an important role in determining the particular biological behavior of nanomaterials. Due to their extreme small size, nanoparticles possess specific large surface area, which makes the number of surface atoms or molecules increasing exponentially. Hence, particles at nanorange exhibit much higher chemical and biological reactivity than fine particles [1]. The risks associated with nanoparticles exposure require investigation due to evidence that these particles can be more inflammogenic and toxic than larger particles comprising of the same material [2]. In recent years, size-dependent toxicity between micro- and nanoscale particles has been demonstrated [3-5].

Carbon black (CB) has wide industrial applications, and used as a reinforcement agent in rubber products, black pigment in printing inks and lithography, electrode for batteries in electrical conductors and during the finishing process of leather goods production. Additionally, carbonaceous nanoparticles are present as an environmental contaminant. Combustion processes are a significant source of carbon nanoparticles. Elemental carbon-based nanoparticles with a diameter of less than $100 \mathrm{~nm}$ are a major part of diesel exhaust and ambient pollution. After deposition in the lungs, larger particles are phagocytized by alveolar and airway macrophages $[6,7]$, but the fine and ultrafine carbon particles remain in the lungs for a longer period of time [8]. Ultrafine particles are phagocytized to a minor extend but they can still enter macrophages and epithelial cells and even penetrate into the circulation. Thus, ultrafine particles not only trigger local inflammatory reactions in the lungs but also cause systemic extrapulmonary effects [9]. Ultrafine particles also have the capacity to inhibit phagocytosis by alveolar macrophages [10]. Macrophages and their monocyte progenitors are major elements of the inflammatory response. In addition to performing phagocytosis, they can release 
inflammatory mediators such as cytokines and chemokines, crucially involved in destruction of microbes and particles using various enzymatic systems [11]. CB nanoparticles are reported to cause cytotoxic injury, increase levels of proinflammatory chemokines, and inhibit cell growth [12]. Epidemiological as well as experimental studies have confirmed the role of CB nanoparticles in aggravating pulmonary disorders such as asthma, lung cancer, pulmonary fibrosis, and systemic cardiovascular disorders [13].

In this study, CB particles were chosen considering their production in huge quantities posing high environmental risk compromising health of general population $[13,14]$. Because of the sporadic information on in vitro size-dependent effect of CB particles, the present study was conducted to determine the effect of their nano- and micron-sized particles on viability, phagocytosis, and cytokine induction in human monocytes, THP-1 cells. These undifferentiated cells express many of the properties of monocytes and represent a model of innate immune system [15]. These cells are an essential link between the adaptive and innate immune responses because they develop into various forms of antigen-presenting cells (macrophages and dendritic cells). They are often used as a model to study human inflammatory responses, which allow for the possibility of elucidating the interactions of nanoparticles with innate immune cells $[16,17]$.

\section{Materials and Methods}

2.1. Particle Preparation and Characterization. Carbon nanopowder $<50 \mathrm{~nm}$ and carbon powder $\sim 500 \mathrm{~nm}$ were purchased from Sigma-Aldrich. Physicochemical properties of particles were analyzed using transmission electron microscopy (TEM), dynamic light scattering (DLS), and zeta potential analyzer. The morphology and size of particles in the stock dispersion were determined by TEM. Dry powder of particles was suspended in cell culture medium at a concentration of $1 \mathrm{mg} / \mathrm{mL}$ and then sonicated at room temperature for 10 minutes to form a homogeneous suspension. After sonication and stabilization, the TEM samples were prepared by drop coating of the stock suspension on carbon-coated copper grids. The films on the grids were allowed to dry prior to measurement. TEM measurements were performed at an accelerating voltage of $120 \mathrm{kV}$ (Model 1200EX, JEOL Ltd., Tokyo, Japan). ZetaPALS (Brookhaven Instruments Corporation, Holtsville, NY) was used to determine the hydrodynamic size and zeta potential of particle suspension in cell culture medium.

2.2. Cell Culture. The human monocytic cell line, THP-1 was obtained from National Centre for Cell Sciences, Pune, India. They were maintained in RPMI 1640 medium supplemented with $10 \%$ heat inactivated fetal bovine serum (FBS), Lglutamine $(2 \mathrm{mM})$, streptomycin $(100 \mu \mathrm{g} / \mathrm{mL})$, and penicillin $(100 \mathrm{U} / \mathrm{mL})$. Cells were cultured at $37^{\circ} \mathrm{C}$ in a humidified atmosphere containing $5 \% \mathrm{CO}_{2}$. THP-1, cells were seeded into 24 -well plates at $1 \times 10^{6}$ cells $/ \mathrm{mL}$ and exposed to particles in the concentration range of 50 to $800 \mu \mathrm{g} / \mathrm{mL}$ for $24 \mathrm{~h}$. Based on the results of screening study (data not shown) done with different concentrations of particles and previous reports $[18,19]$, a concentration range was selected. The cells were exposed within $10 \mathrm{~min}$ of preparation of nano- and micro$\mathrm{CB}$ suspensions. Cell-free controls were included in order to assess the interference of particles with each assay.

2.3. Assessment of Cytotoxicity. THP-1 cells were incubated with $\mathrm{CB}$ particles (nano and micro) in a concentration range of $50,100,200,400$, and $800 \mu \mathrm{g} / \mathrm{mL}$ for $24 \mathrm{~h}$. Following this incubation period, cytotoxicity of particles was assessed using MTT assay [20]. Briefly, MTT $(20 \mu \mathrm{L}$ per well of $5 \mathrm{mg} / \mathrm{mL}$ stock) was added and incubated for $4 \mathrm{~h}$. Supernatants were removed by centrifugation and then $300 \mu \mathrm{L}$ of DMSO was added. After thorough mixing, optical density at $570 \mathrm{~nm}$ was detected by microplate reader (BioTek, USA). Control values (without stimuli) were set at $100 \%$ viable and all values were expressed as a percentage of the control and respective TC-50 (particle concentration inducing 50\% cell mortality) concentrations were calculated using GraphPad Prism software.

2.4. Phagocytosis Assay. The phagocytic ability of THP-1 cells after $4 \mathrm{~h}$ exposure to varying concentrations of $\mathrm{CB}$ particles (namely, 1/2TC,50, TC50 and 2TC50) was assessed by measuring their ability to phagocytose $1 \mu \mathrm{m}$ latex beads ( $1 \mu \mathrm{m}$ Latex beads, carboxylate modified polystyrene, and fluorescent yellow-green). The method used was modified method of Schroeder and Kinden [21]. After exposure, cells were washed two times with PBS to remove excess particles. Culture medium containing latex beads at a bead-to-cell ratio of $10: 1$ was transferred to the culture wells. Monocyte and bead suspensions were then incubated for $1 \mathrm{~h}$ to allow phagocytosis. Beads not phagocytosed were removed by centrifugation at $225 \mathrm{~g}$ for $5 \mathrm{~min}$; the cell pellet was then resuspended in phosphate buffer saline. The process was repeated three times and finally the cells were vortexed for $10 \mathrm{~s}$ and fluorescence of the cells was determined at an excitation and emission wavelengths set at 440 and $485 \mathrm{~nm}$, respectively. Cell viability during phagocytosis assay was monitored by trypan blue exclusion. Viability was $95 \pm 5 \%$ throughout the assay. Microscopic images of phagocytosed latex beads, only at one concentration, that is, TC-50 concentration of test particles, were taken. After washing, the cells were seen under microscope. DIC images or paired DIC and fluorescence images of phagocytosed beads by monocytes were acquired using fluorescent microscope (Zeiss, Germany) with 40x dry and 100x (oil immersion) objectives.

2.5. Cytokine Analysis. To investigate the effect of CB particles on cytokine production, an enzyme linked immunosorbent assay (ELISA) was performed. For determination of IL$1 \beta$, IL- 6, TNF- $\alpha$, and IL- 8 , monocytes were cultured at $1 \times$ $10^{6}$ cells $/ \mathrm{mL}$ and were exposed to TC-50 concentration of $\mathrm{CB}$ particles (nano carbon: $591.4 \mu \mathrm{g} / \mathrm{mL}$ and micro carbon $687.1 \mu \mathrm{g} / \mathrm{mL}$ ) for $6,18,24$, and $48 \mathrm{~h}$. After particle exposure, cell-free supernatants were harvested via successive $10 \mathrm{~min}$ centrifugations $(2,000 \mathrm{rpm}, 7,000 \mathrm{rpm}$, and 13,000 rpm) and 
TABLE 1: Primer sequence of cyclooxygenase-2 (COX-2), monocyte chemoattractant protein-1 (MCP-1), and 18S rRNA gene used in this study.

\begin{tabular}{lccc}
\hline Primer name & Primer sequences & $T_{m}$ & Number of cycles performed \\
\hline COX-2 & $\begin{array}{l}\text { F: TTCAAATGAGATTGTGGGAAAATT } \\
\text { R: AGATCATCTCTGCCTGAGTATCTT }\end{array}$ & 59.1 & 35 \\
\hline MCP-1 & $\begin{array}{l}\text { F: AATCAATGCCCCAGTCACCTGC } \\
\text { R: CGCAGTTTGGGTTTGCTTGTCC }\end{array}$ & 62.1 & 35 \\
\hline 18 rRNA & $\begin{array}{l}\text { F: GTAACCCGTTGAACCCCATT } \\
\text { R: CCATCCAATCGGTAGTAGCG }\end{array}$ & 58.3 & 35 \\
\hline
\end{tabular}

TABLE 2: Particle characterization.

\begin{tabular}{|c|c|c|c|c|c|c|}
\hline Particles & Description & Average size ${ }^{\mathrm{a}}$ & $\begin{array}{c}\text { Size using } \\
\mathrm{TEM}^{\mathrm{b}}(\mathrm{nm})\end{array}$ & $\begin{array}{l}\text { Size in media } \\
(\mathrm{nm})\end{array}$ & $\mathrm{PDI}^{\mathrm{d}}$ & $\begin{array}{c}\text { Zeta potential }^{\mathrm{e}} \\
(\mathrm{mV})\end{array}$ \\
\hline Nanocarbon & Carbon nanopowder & $<50 \mathrm{~nm}$ & $53.7 \pm 10.2$ & $235.5 \pm 24.9$ & $0.005 \pm 0.001$ & $-39.9 \pm 4.91$ \\
\hline Microcarbon & Carbon & $\sim 500 \mathrm{~nm}$ & $524.9 \pm 8.1$ & $636.7 \pm 17.2$ & $0.074 \pm 0.008$ & $-15.6 \pm 6.37$ \\
\hline
\end{tabular}

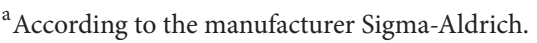

${ }^{\mathrm{b}}$ Using transmission electron microscopy.

c,d, and e Using ZetaPALS.

PDI: polydispersity index.

stored at $-80^{\circ} \mathrm{C}$ until analysis. ELISA was performed according to the manufacturer's protocol (Abcam ELISA Kit) and absorbance values were measured using microplate reader (BioTek Instruments, USA). A minimum of three independent experiments were performed and concentrations calculated from the linear regression equation were derived from a set of standard absorbance values.

2.6. Gene Expression Analysis. Gene expression analysis of COX-2 and MCP-1 was evaluated by exposing cells to TC-50 concentration of CB particles (nano carbon: $591.4 \mu \mathrm{g} / \mathrm{mL}$ and micro carbon $687.1 \mu \mathrm{g} / \mathrm{mL}$ ) for $24 \mathrm{~h}$. Total RNA were isolated using RNeasy Mini Kit (Qiagen, USA). The concentration and integrity of RNA was measured using multimode microplate reader (BioTek, USA) prior to the experiment. The Enhanced Avian HS RT-PCR kit (Sigma, USA) was used for the amplification of COX-2, MCP-1, and 18 sRNA gene, according to the manufacturer's instructions. Amplified cDNA products were separated on $1.2 \%$ agarose gel by electrophoresis. The primer sequences of amplified genes were shown in Table 1.

2.7. Detection of DNA Damage. THP-1 cells exposed to nano- and microparticles of CB $(0,50,100,200,400$, and $800 \mu \mathrm{g} / \mathrm{mL}$ ) for $24 \mathrm{~h}$ were collected into tubes and washed with PBS. The cells were incubated for $3 \mathrm{~h}$ in lysis buffer (20 mM Tris-HCl, pH 8.0, 5 mM EDTA, $0.1 \mathrm{M} \mathrm{NaCl}, 0.5 \%$ SDS, and $100 \mu \mathrm{g} / \mathrm{mL}$ RNase) at $37^{\circ} \mathrm{C}$. After incubation, phenol: chloroform $(1: 1)$ mixture was used to extract DNA. By adding an equal volume of ice-cold absolute isopropanol, DNA was precipitated. DNA was dissolved in $50 \mu \mathrm{L}$ of $1 \mathrm{X}$ TE (10 mM Tris, $1 \mathrm{mM}$ EDTA, and $\mathrm{pH} 8.0$ ) buffer. $20 \mu \mathrm{g}$ of DNA was loaded onto $1.2 \%$ agarose gel and electrophoresis was carried out at $60 \mathrm{~V}$ for $2 \mathrm{~h}$ with TBE as the running buffer. DNA in the gel was visualized under UV light [22].
2.8. Statistical Analysis. Statistical analysis was carried out with GraphPad Prism 4 statistical software (Graphpad Software Inc., CA, USA). One-way analysis of variance (ANOVA) with Tukey's method for multiple comparisons was used to evaluate the various responses induced by different concentrations of particles and statistical comparisons between particle sizes were performed with two-way ANOVA, followed by a Bonferroni posttest. Differences were considered statistically significant when the $P$ value was less than 0.05 .

\section{Results}

3.1. Particle Characterization. TEM analysis was performed to determine the morphology and size of the particle and micrographs are shown in Figure 1. The particles were found nearly spherical and cubical in shape. The primary sizes of the particles estimated from TEM images (Figure 1) were presented in Table 2. Since nanoparticles often form agglomerates in a solution, the hydrodynamic sizes of the dispersed particles and their agglomerates in cell culture medium were estimated using ZetaPALS. These values were found larger than the per se particle size measured by TEM (Table 2).

3.2. Cell Viability. After $24 \mathrm{~h}$ exposure of THP-1 cells to varying doses $(50,100,200,400$, and $800 \mu \mathrm{g} / \mathrm{mL})$ of nano- and micro-CB particles, cellular metabolic activity was detected by MTT assay. The cell viability decreased in a concentrationand size-dependent manner following exposure to CB particle (Figure 2) and a significant decrease was observed at concentration from 100 to $800 \mu \mathrm{g} / \mathrm{mL}$ for nano carbon particles and at 400 and $800 \mu \mathrm{g} / \mathrm{mL}$ for micro carbon particles. The nano carbon particles decreased the percentage of cell viability from $82 \%$ to $41 \%$ while micro carbon particles decreased it from $69 \%$ to $56 \%$. The significant size selective difference $(P<0.01)$ between nano- and micro carbon was 


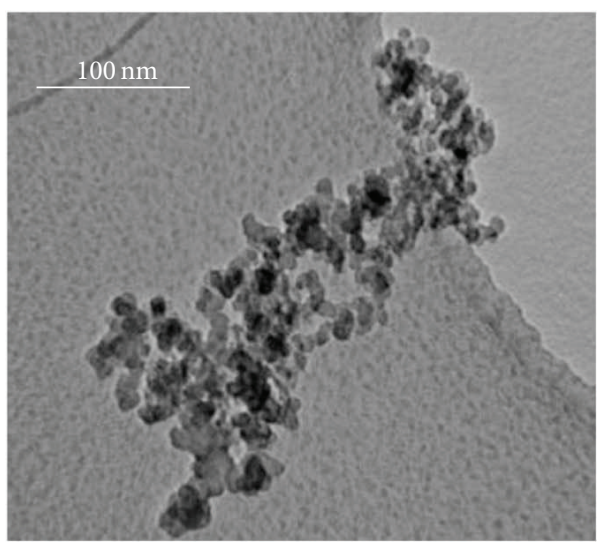

(a)

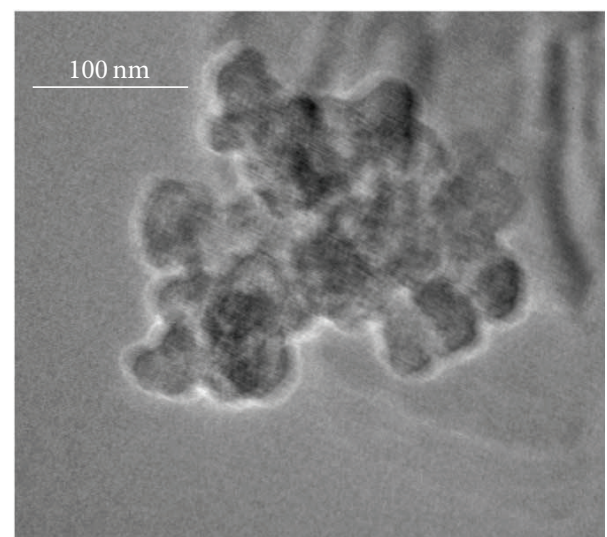

(b)

FIgURE 1: Transmission electron micrograph of carbon particles: (a) nanocarbon and (b) microcarbon. Scale bar is $100 \mathrm{~nm}$.

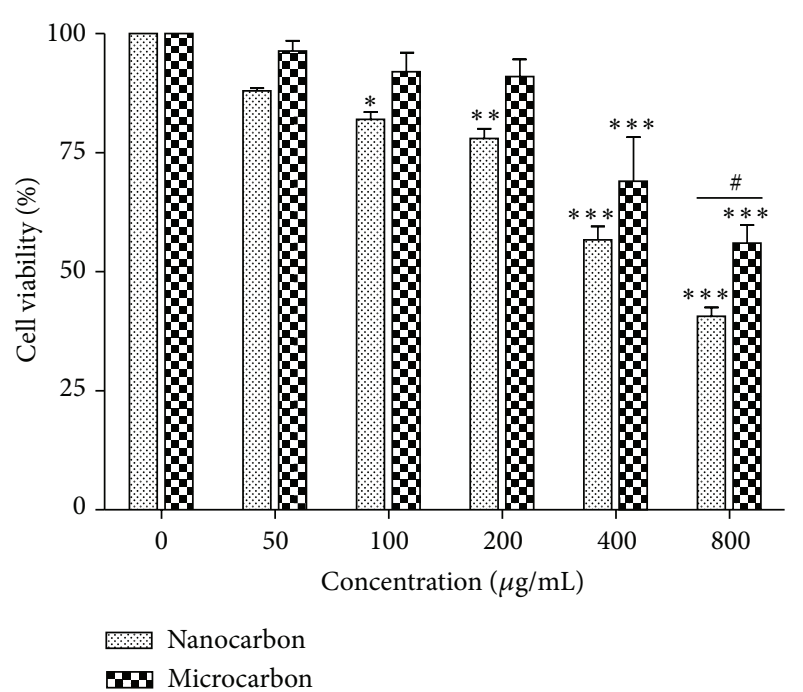

FIGURE 2: Percentage of the metabolic activity of THP-1 cells upon exposure to varying concentrations of carbon particles, as determined by the MTT assay. Cells were exposed to 50, 100, 200,400 and $800 \mu \mathrm{g} / \mathrm{mL}$ of nano- and microcarbon particles for $24 \mathrm{~h}$. The results are expressed as a percentage relative to controls and are presented as mean \pm SEM of three independent replicate experiments. Significance is indicated by ${ }^{*} P<0.05,{ }^{* *} P<0.01$ and ${ }^{* * *} P<0.001$, versus control. ${ }^{\#} P<0.05$ indicates significant difference between the particle sizes.

found only at highest concentration of $800 \mu \mathrm{g} / \mathrm{mL}$. The TC50 value (particle concentration causing $50 \%$ cell mortality) calculated for nano- and micro carbon was found to be $591.4 \mu \mathrm{g} / \mathrm{mL}$ and $687.1 \mu \mathrm{g} / \mathrm{mL}$, respectively (Table 3 ).

3.3. Phagocytic Capacity of THP-1 Cells. The phagocytic ability of the monocytes was measured after the uptake of test particles. The assay was carried out by taking 3 different concentrations of test particle, namely, 1/2 TC-50, TC-50, and 2TC-50 for each particle. A significant reduction in the phagocytosis of indicator latex beads occurred after exposure to all concentrations of nano-CB particles $(P<0.01)$, while
TABLE 3: Calculated TC-50 concentrations.

\begin{tabular}{lcc}
\hline \multirow{2}{*}{ Cell type } & \multicolumn{2}{c}{ Carbon particles } \\
& Nanocarbon & Microcarbon \\
\hline \multirow{2}{*}{ THP-1 } & $591.4 \mu \mathrm{g} / \mathrm{mL}$ & $687.1 \mu \mathrm{g} / \mathrm{mL}$ \\
& $(490.0$ to 713.6$)$ & $(506.9$ to 931.3$)$ \\
\hline
\end{tabular}

no significant reduction was observed with their microsize (Figure 3). Fluorescent images represent monocytes phagocytosing latex beads (Figure 4). Qualitatively control cells were found to phagocytose more beads as compared to nano-CB particle exposed monocytes whereas the phagocytic capacity of monocytes was not affected by the presence of micro-CB particles (Figure 5).

3.4. Proinflammatory Cytokine. Monocytes secrete inflammatory mediators like cytokines upon stimulation by various agents. The cellular release of the proinflammatory cytokine (IL- $1 \beta$, TNF- $\alpha$, and IL- 6 ) and chemokine (IL- 8 ) into the culture medium was measured when monocytes were exposed to TC-50 concentration of $\mathrm{CB}$ particle at different time points $(6,18,24$, and $48 \mathrm{~h})$ (Figure 6). Carbon particles showed significant size- and time-dependent release of IL-1 $\beta$, IL-6, TNF- $\alpha$, and IL-8 from THP-1 cells (Figures 6(a), 6(b), 6(c), and $6(\mathrm{~d}))$. In case of nano-CB particles, there was timedependent release of cytokine up to $24 \mathrm{~h}$ which declined thereafter while it remained increasing up to $48 \mathrm{~h}$ in case of micro-CB particles. The nanosized particles were more potent than the larger particles in inducing the release of all the cytokines $(P<0.001)$.

3.5. MCP-1 and COX-2 mRNA Expression. A significant upregulation of MCP-1 gene expression was observed with both sizes of $\mathrm{CB}$ particles (Figure 7(a)). Micron size of $\mathrm{CB}$ particles exhibited more expression of MCP-1 gene than nanosize (Figure $7(\mathrm{c})$ ). However, no significant change was observed in COX-2 gene expression by both sizes of $\mathrm{CB}$ particles (Figures 7(a) and 7(b)) as compared to control. 

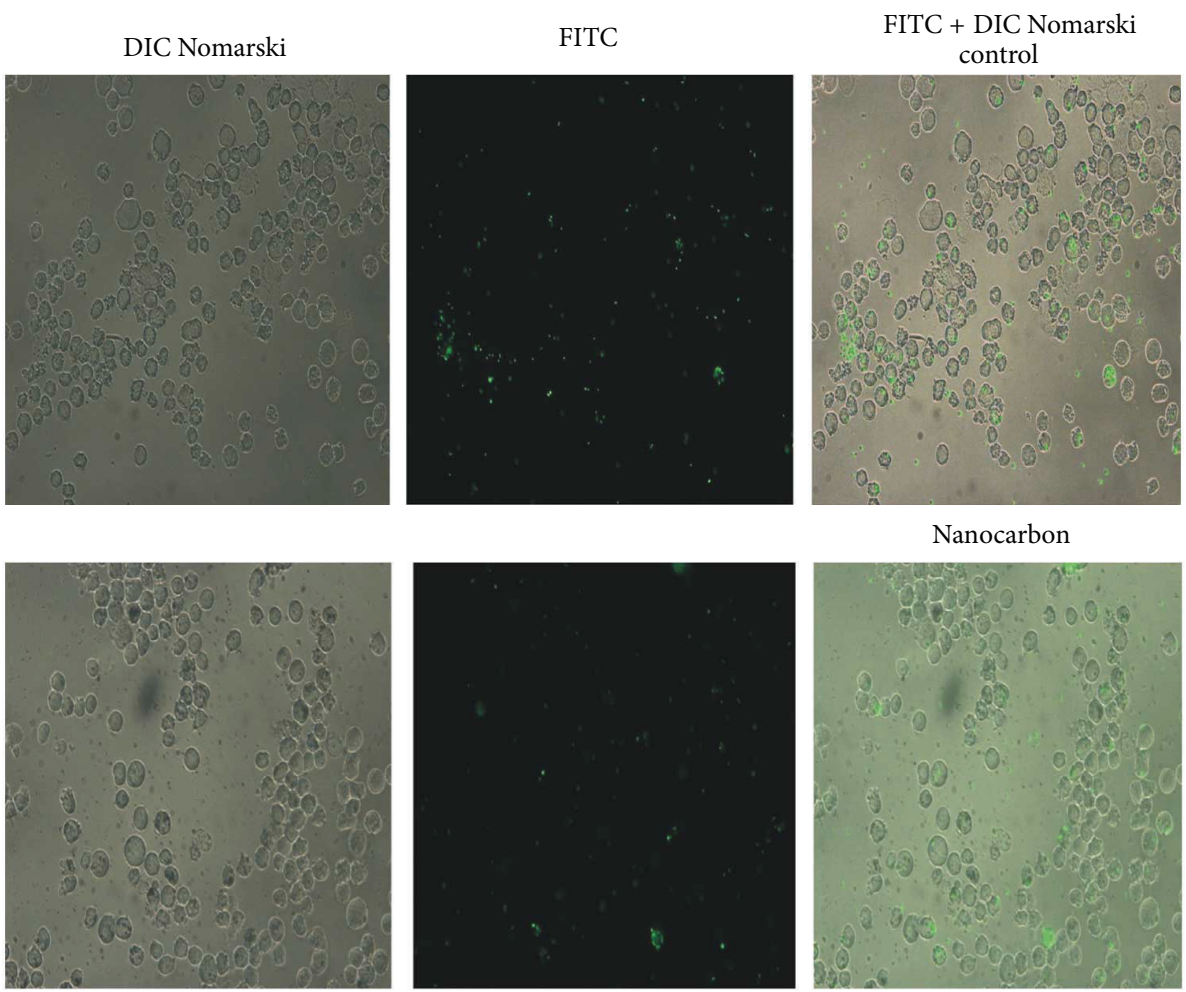

Nanocarbon

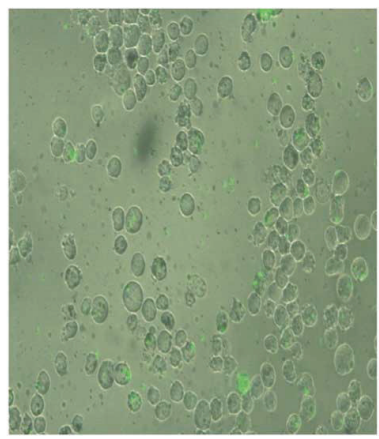

Microcarbon
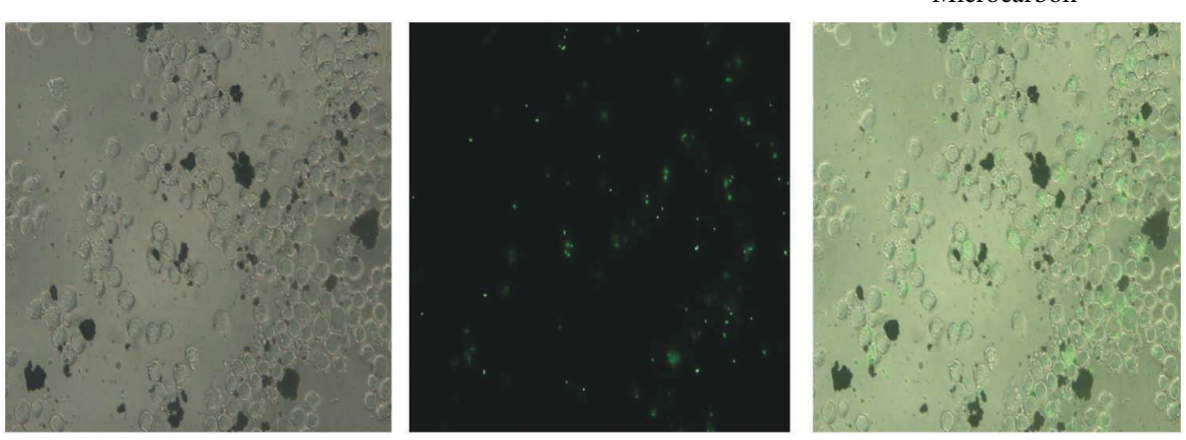

FIGURE 3: Photomicrographs of THP-1 cells phagocytosing latex beads. THP-1 cells were incubated with TC-50 concentration of carbon particles (nano carbon: $591.4 \mu \mathrm{g} / \mathrm{mL}$ and micro carbon $687.1 \mu \mathrm{g} / \mathrm{mL}$ ) for $4 \mathrm{~h}$; then, latex beads were allowed to phagocytose by THP-1 cells for 1h. After washing, fluorescent images were taken (magnification 400x).

3.6. DNA Analysis of THP-1 Cells. DNA damage was studied by observing smearing pattern on agarose gel under UV light. Exposure of THP-1 cells to both sizes of CB particles for $24 \mathrm{~h}$ did not exhibit any smearing pattern on agarose gel (Figure 8).

\section{Discussion}

The inconsistencies of the effects of different CB samples in relation to carcinogenicity and toxicity were reported $[23,24]$. These inconsistencies are likely to be related to variation in the particle sizes between the different samples. Therefore, the present in vitro study compared the potential differences in the ability of nano- and micro-CB particles to produce toxicity on exposure to human monocytes, THP-1. The physicochemical characteristics of nano- and micron size of CB particles were extensively characterized. The average size of the particles was in agreement with the size provided by the supplier. DLS analysis revealed a hydrodynamic size of dispersed particles in cultured medium indicating agglomeration in aqueous media which was further corroborated by zeta potential measurement. Needless to surprise, the mean particle sizes and size distribution of particles (measured by DLS) were found enhanced when measured in aqueous media compared to measurements in the dry phase (measured by TEM). To minimize the effects of particles aggregation and sedimentation, suspension of particles was always freshly prepared and sonicated before each experiment.

In this study, the cytotoxicity results demonstrated that nanoparticles of $\mathrm{CB}$ were more potent than its micron size in causing toxicity to THP-1 cells as revealed by MTT assay. Both 

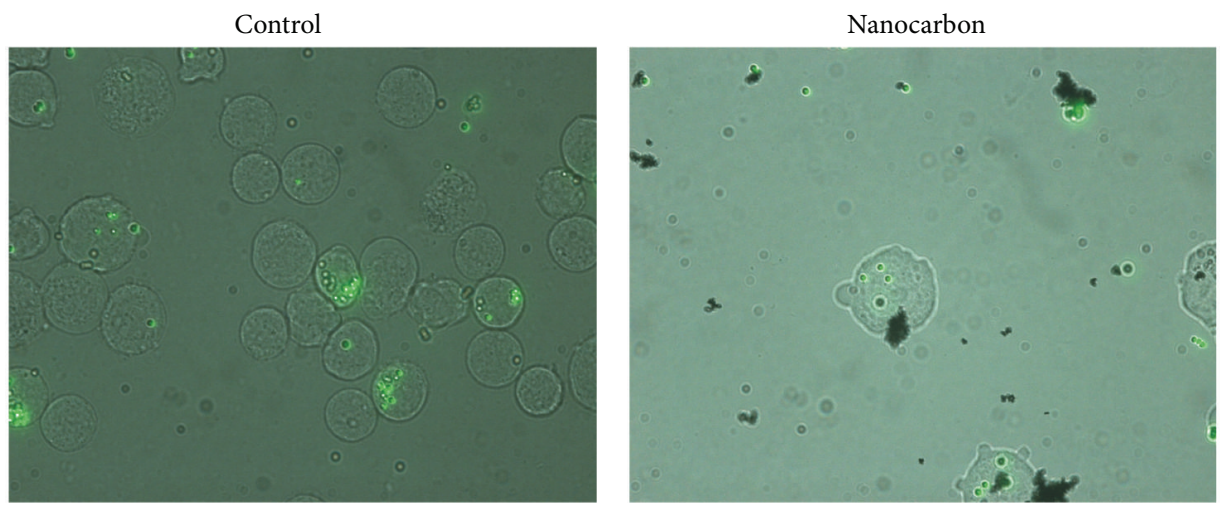

Microcarbon

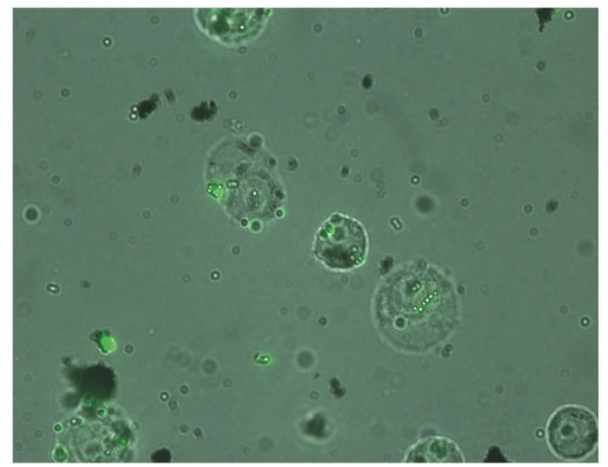

FIGURE 4: Representative photomicrographs of THP-1 cells phagocytosing latex beads (magnification 1000x).

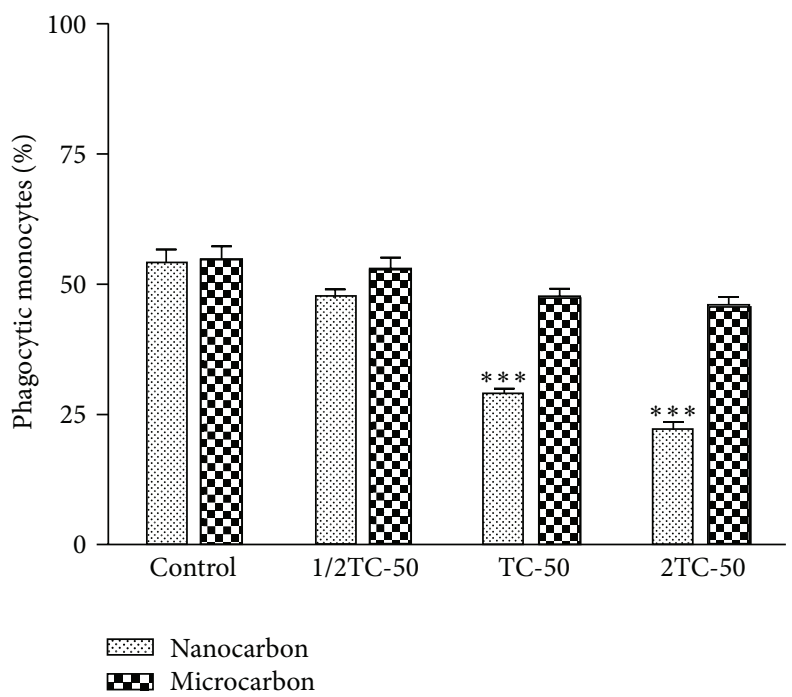

Figure 5: Percentage of cells capable of phagocytosing the indicator latex beads after the uptake of test particles (i.e., phagocytic monocytes). Cells were exposed to $1 / 2 \mathrm{TC}-50$, TC-50, and $2 \mathrm{TC}-50$ concentrations of nano carbon $(295.7 \mu \mathrm{g} / \mathrm{mL}, 591.4 \mu \mathrm{g} / \mathrm{mL}$, and $1182.8 \mu \mathrm{g} / \mathrm{mL}$, resp.) and micro carbon $(343.5 \mu \mathrm{g} / \mathrm{mL}, 687.1 \mu \mathrm{g} / \mathrm{mL}$ and $1374.2 \mu \mathrm{g} / \mathrm{mL}$, resp.) for $4 \mathrm{~h}$. The results are expressed as a percentage relative to controls and are presented as mean \pm SEM of three independent replicate experiments. Significance is indicated by ${ }^{* *} P<0.01$ versus control.

sizes of particles followed concentration-dependent toxicity in monocytes. The effect of $\mathrm{CB}$ particle on phagocytic ability of monocytes was also demonstrated. It was found that only nano-CB particle impaired the phagocytic capacity of monocytes. Our findings of impaired phagocytosis in nano-CB particle exposed cells support the findings of Renwick et al. who demonstrated that ultrafine $\left(\mathrm{CB}\right.$ and $\left.\mathrm{TiO}_{2}\right)$ particles impaired macrophage phagocytosis to a greater extent than fine particles compared on a mass basis [25].

The study of inflammatory responses of THP- 1 cells on exposure to nano- and micro particles of $\mathrm{CB}$ revealed the induction of proinflammatory cytokines IL-1 $\beta$, IL-6, and 


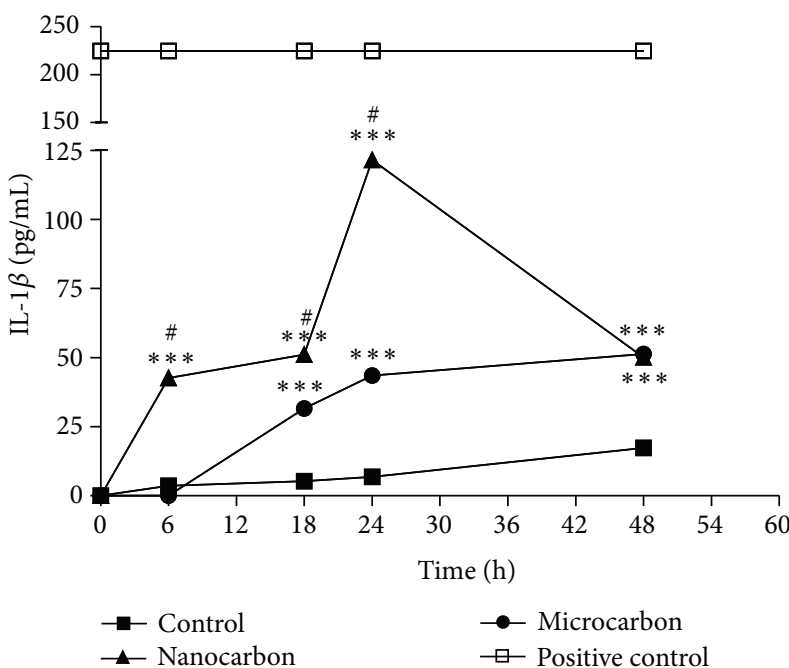

(a)

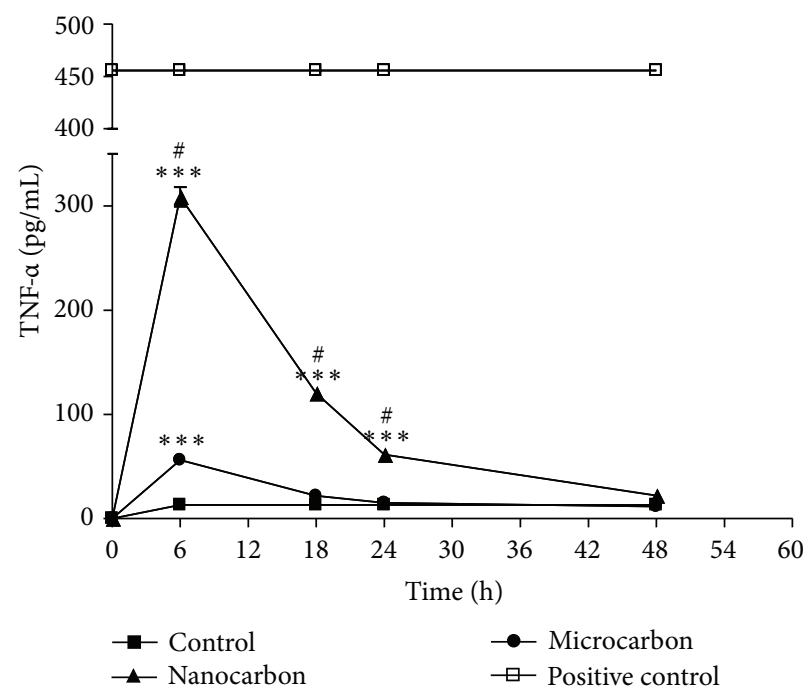

(c)

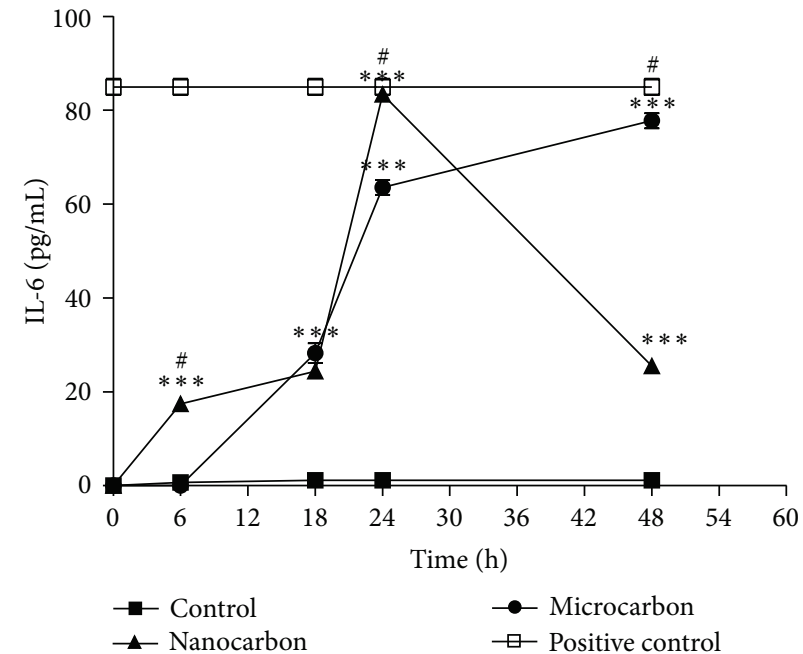

(b)

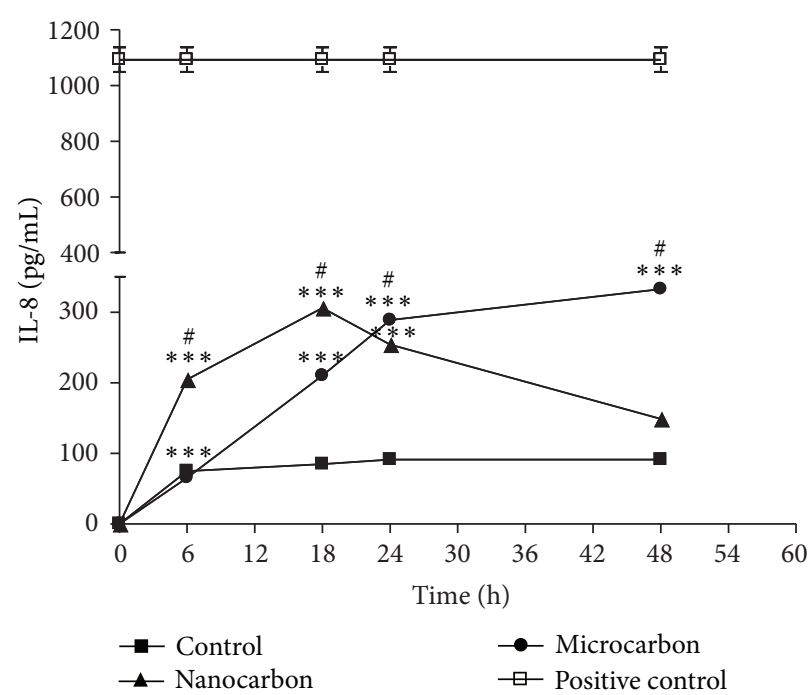

(d)

Figure 6: Proinflammatory cytokine and chemokine level in THP-1 cells exposed to carbon particles at their TC-50 concentration (nano carbon: $591.4 \mu \mathrm{g} / \mathrm{mL}$ and micro carbon $687.1 \mu \mathrm{g} / \mathrm{mL}$ ) for different times $(0,6,18,24$, and $48 \mathrm{~h})$ as determined by ELISA. A positive control for each assay was run in parallel as per manufacturer's instruction. (a) IL-1 $\beta$ level, (b) IL-6 level, (c) TNF- $\alpha$ level, and (d) IL-8 level. Results are presented as mean \pm SEM of three independent replicate experiments. Significance is indicated by ${ }^{* * *} P<0.001$ versus control. ${ }^{\#} P<0.001$ indicates significant difference between the particle sizes.

TNF- $\alpha$. Many cytokines including IL-1, IL-6, and TNF$\alpha$ activate functions of inflammatory cells during acute inflammatory responses. These cytokines increase the vascular permeability and thus cause swelling and redness associated with inflammation. IL-1 and IL-6 are responsible for fever reactions while TNF- $\alpha$ stimulates endothelial cells and is responsible for hypotension [26]. The nanoform of $\mathrm{CB}$ particle showed increase in release of IL- $1 \beta$ and IL6 with increasing time of exposure up to $24 \mathrm{~h}$ and then declined thereafter distinctly from its micron form. TNF$\alpha$ secretion was induced at early time point, that is, at $6 \mathrm{~h}$, which later on decreased with time. It was observed that the secretion of IL- $1 \beta$, IL- 6 , and TNF- $\alpha$ cytokines was more profound with nanosize than with micron size. This suggests that the response of particles to proinflammatory cytokine release was size dependent. Chemokines are secondary proinflammatory mediators; that is, they are typically induced by primary proinflammatory mediators such as IL-1 or TNF. In the present study, gene expression of MCP-1, a CC chemokine, and release of IL- 8 , a member of the CXC chemokine subfamily, were studied. MCP-1 stimulates both chemotaxis of monocytes and several cellular events associated with chemotaxis. The result of the present study demonstrated the stimulation of chemotaxis as revealed by upregulation of MCP-1 gene and increased release of IL8 on exposure to $\mathrm{CB}$ particles. Niwa et al. [27] have also shown the upregulation of IL-6 and MCP-1 in rats after inhalation exposure of CB and substantiate the findings. IL-8 


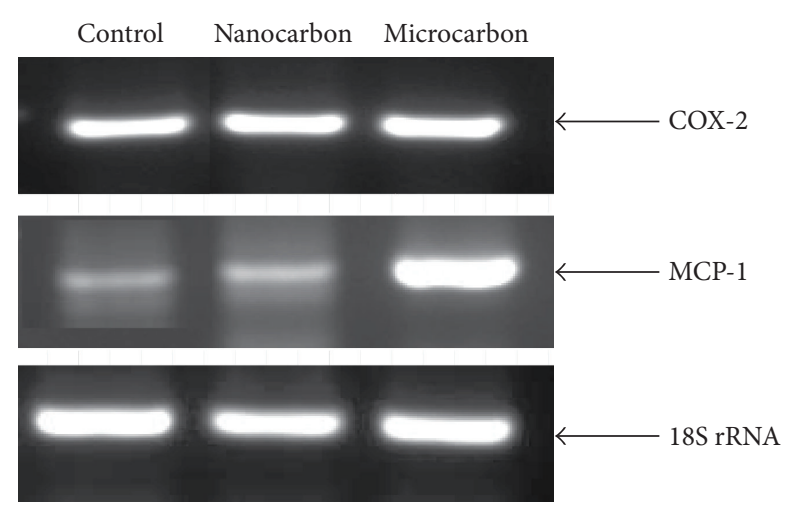

(a)

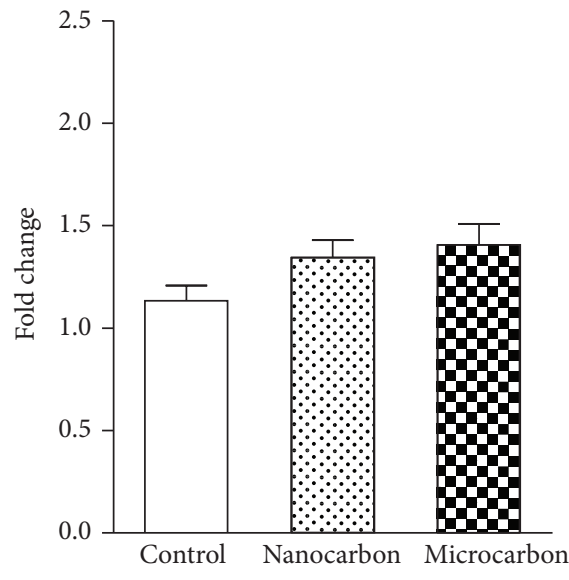

(b)

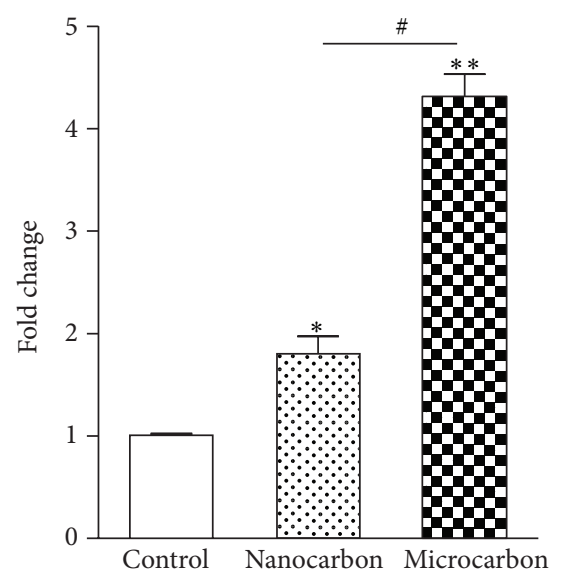

(c)

FIGURE 7: Effects of carbon particles (nano and micro) on mRNA levels of COX-2 and MCP-1 gene. THP-1 cells were exposed to carbon particles at their TC-50 concentration (nano carbon: $591.4 \mu \mathrm{g} / \mathrm{mL}$ and micro carbon $687.1 \mu \mathrm{g} / \mathrm{mL}$ ). (a) COX-2 and MCP-1 gene expression on agarose gel. Gene expressions are analyzed by densitometric analysis using Image J software. Results are also expressed as a fold change over the control group. (b) Densitometric bar diagram of COX-2 gene. (c) Densitometric bar diagram of MCP-1 gene. Statistically significant differences were assessed as compared to the controls $\left({ }^{*} P<0.05\right.$ and $\left.{ }^{* *} P<0.01\right)$. ${ }^{\#} P<0.001$ indicates significant difference between the particle size.

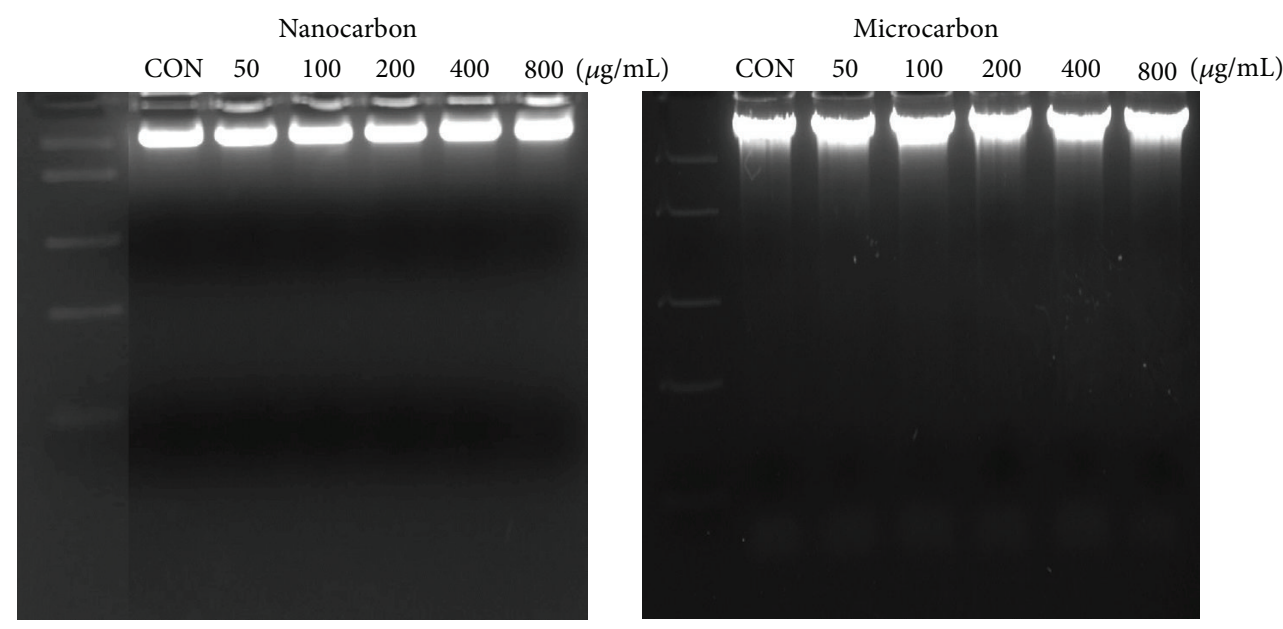

Figure 8: Effect of carbon particles (nano and micro) on DNA of THP-1 cells. The cells were exposed to 50, 100, 200, 400, and 800 $\mu \mathrm{g} / \mathrm{mL}$ of carbon particles for $24 \mathrm{~h}$. Equal amount of DNA $(20 \mu \mathrm{g})$ was loaded on agarose gel and visualized under UV light. 
is a chemokine which plays a key role in the activation of neutrophils and their recruitment to the site of inflammation [28]. Results demonstrated increase in the release of IL- 8 with time after exposure to both sizes of CB particles. Kim et al. [29] reported increased expression of IL-8 mRNA and protein on exposure of ultrafine carbon particles in normal human bronchial epithelial cells and supported the findings. Noticeably, the MCP-1 gene expression was more upregulated by micron size of $\mathrm{CB}$ than nanosize. Similar results were observed with another chemokine, IL-8, where micron size of $\mathrm{CB}$ was able to induce more secretion of IL- 8 at later time of exposure. Another inflammatory marker, COX-2, was also studied. COX-2, an inducible isoform of cyclooxygenase, is induced by several mitogenic and proinflammatory stimuli including LPS, interleukin-1 (IL- $1 \alpha$ and IL-1 $\beta$ ), and TNF- $\alpha$ $[30,31]$. In the present study, CB particles did not show any change in the COX-2 expression. Overall, in accordance with the results of Ferin et al. [32] and Li et al. [33], it was found that nano-CB induced a greater toxicity and inflammatory response than micro- $\mathrm{CB}$ in human monocytes.

In the present study, the effect of $\mathrm{CB}$ particles on DNA damage of human monocytes was also studied. In assessing toxicity, DNA damage to macrophages is an important outcome since (i) these cells remove inhaled NPs [34] and (ii) DNA damage is considered to be an important initial event in various diseases including carcinogenesis [35]. The results showed that there was no smearing pattern observed on agarose gel indicating that both sizes of CB particles did not cause any DNA damage.

In conclusion, a comparative toxicity study between nano- and micro-CB particle resulted in size-dependent cytotoxicity and increased inflammatory responses in human monocytes, THP-1 cells. Nano-CB particles altered the phagocytic capacity of monocytes although micro-CB had no significant effect on phagocytic capacity of monocytes. However, both sizes of $\mathrm{CB}$ particle did not have any effect on DNA of THP-1 cells. Further studies are required to elucidate the exact pathway of inflammatory response induced by $\mathrm{CB}$ particles in immune cells.

\section{Conflict of Interests}

The authors declare that there is no conflict of interests.

\section{Acknowledgments}

The authors are thankful to the Director of Defence Research and Development Establishment, Gwalior, India, for providing facility. They acknowledge Advanced Instrumentation Research Facility (AIRF), Jawaharlal Nehru University (JNU), New Delhi, India, for nanoparticle characterization by TEM. The hydrodynamic size and zeta potential measurements of particles were performed using facilities at CeNSE, funded by Department of Information Technology, Government, of India and Indian Institute of Science, Bangalore, India.

\section{References}

[1] A. Nel, T. Xia, L. Mädler, and N. Li, “Toxic potential of materials at the nanolevel," Science, vol. 311, no. 5761, pp. 622-627, 2006.

[2] "Nanoscience and nanotechnologies: opportunities and uncertainties," The Royal Society and The Royal Academy of Engineers, 2004, http://royalsociety.org/policy/publications/2004/ nanoscience-nanotechnologies/.

[3] D. M. Brown, M. R. Wilson, W. MacNee, V. Stone, and K. Donaldson, "Size-dependent proinflammatory effects of ultrafine polystyrene particles: a role for surface area and oxidative stress in the enhanced activity of ultrafines," Toxicology and Applied Pharmacology, vol. 175, no. 3, pp. 191-199, 2001.

[4] K. Midander, P. Cronholm, H. L. Karlsson et al., "Surface characteristics, copper release, and toxicity of nano- and micrometer-sized copper and copper(ll) oxide particles: a cross-disciplinary study," Small, vol. 5, no. 3, pp. 389-399, 2009.

[5] B. Wang, W.-Y. Feng, T.-C. Wang et al., "Acute toxicity of nanoand micro-scale zinc powder in healthy adult mice," Toxicology Letters, vol. 161, no. 2, pp. 115-123, 2006.

[6] W. Möller, D. M. Brown, W. G. Kreyling, and V. Stone, "Ultrafine particles cause cytoskeletal dysfunctions in macrophages: role of intracellular calcium," Particle and Fibre Toxicology, vol. 2, article 7, 2005.

[7] M. Dörger and F. Krombach, "Response of alveolar macrophages to inhaled particulates," European Surgical Research, vol. 34, no. 1-2, pp. 47-52, 2002.

[8] P. Gehr, F. Blank, and B. M. Rothen-Rutishauser, "Fate of inhaled particles after interaction with the lung surface," Paediatric Respiratory Reviews, vol. 7, supplement 1, pp. S73-S75, 2006.

[9] G. Oberdörster, E. Oberdörster, and J. Oberdörster, "Nanotoxicology: an emerging discipline evolving from studies of ultrafine particles," Environmental Health Perspectives, vol. 113, no. 7, pp. 823-839, 2005.

[10] K. Donaldson, V. Stone, A. Clouter, L. Renwick, and W. MacNee, "Ultrafine particles," Occupational and Environmental Medicine, vol. 58, no. 3, pp. 211-216, 2001.

[11] S. F. van Eeden, A. Yeung, K. Quinlam, and J. C. Hogg, "Systemic response to ambient particulate matter: relevance to chronic obstructive pulmonary disease," Proceedings of American Thoracic Society, vol. 2, no. 1, pp. 61-67, 2005.

[12] H. Yamawaki and N. Iwai, "Mechanisms underlying nano-sized air-pollution-mediated progression of atherosclerosis carbon black causes cytotoxic injury/inflammation and inhibits cell growth in vascular endothelial cells," Circulation Journal, vol. 70, no. 1, pp. 129-140, 2006.

[13] K. Donaldson, L. Tran, L. A. Jimenez et al., "Combustionderived nanoparticles: a review of their toxicology following inhalation exposure," Particle and Fibre Toxicology, vol. 2, article 10, 2005.

[14] K. Unfried, U. Sydlik, K. Bierhals, A. Weissenberg, and J. Abel, "Carbon nanoparticle-induced lung epithelial cell proliferation is mediated by receptor-dependent Akt activation," American Journal of Physiology - Lung Cellular and Molecular Physiology, vol. 294, no. 2, pp. L358-L367, 2008.

[15] S. Tsuchiya, M. Yamabe, Y. Yamaguchi, Y. Kobayashi, T. Konno, and K. Tada, "Establishment and characterization of a human acute monocytic leukemia cell line (THP-1)," International Journal of Cancer, vol. 26, no. 2, pp. 171-176, 1980.

[16] M. A. Dobrovolskaia, P. Aggarwal, J. B. Hall, and S. E. McNeil, "Preclinical studies to understand nanoparticle interaction with 
the immune system and its potential effects on nanoparticle biodistribution," Molecular Pharmaceutics, vol. 5, no. 4, pp. 487495, 2008.

[17] S. A. Nicholas and V. V. Sumbayev, "The involvement of hypoxia-inducible factor 1 alpha in toll-like receptor 7/8-mediated inflammatory response," Cell Research, vol. 19, no. 8, pp. 973983, 2009.

[18] M. Davoren, E. Herzog, A. Casey et al., "In vitro toxicity evaluation of single walled carbon nanotubes on human A549 lung cells," Toxicology in Vitro, vol. 21, no. 3, pp. 438-448, 2007.

[19] P. G. Barlow, A. Clouter-Baker, K. Donaldson, J. MacCallum, and V. Stone, "Carbon black nanoparticles induce type II epithelial cells to release chemotaxins for alveolar macrophages," Particle and Fibre Toxicology, vol. 2, article 11, 2005.

[20] F. Denizot and R. Lang, "Rapid colorimetric assay for cell growth and survival: modifications to the tetrazolium dye procedure giving improved sensitivity and reliability," Journal of Immunological Methods, vol. 89, no. 2, pp. 271-277, 1986.

[21] F. Schroeder and D. A. Kinden, "Measurement of phagocytosis using fluorescent latex beads," Journal of Biochemical and Biophysical Methods, vol. 8, no. 1, pp. 15-27, 1983.

[22] R. T. Allen, W. J. Hunter III, and D. K. Agrawal, "Morphological and biochemical characterization and analysis of apoptosis," Journal of Pharmacological and Toxicological Methods, vol. 37, no. 4, pp. 215-228, 1997.

[23] K. E. Driscoll, J. M. Carter, B. W. Howard et al., "Pulmonary inflammatory, chemokine, and mutagenic responses in rats after subchronic inhalation of carbon black," Toxicology and Applied Pharmacology, vol. 136, no. 2, pp. 372-380, 1996.

[24] G. Oberdörster, "Significance of particle parameters in the evaluation of exposure-dose-response relationships of inhaled particles," Inhalation Toxicology, vol. 8, pp. S73-S89, 1996.

[25] L. C. Renwick, K. Donaldson, and A. Clouter, "Impairment of alveolar macrophage phagocytosis by ultrafine particles," Toxicology and Applied Pharmacology, vol. 172, no. 2, pp. 119127, 2001.

[26] M. Elsabahy and K. L. Wooley, "Cytokines as biomarkers of nanoparticle immunotoxicity," Chemical Society Review, vol. 42, no. 12, pp. 5555-5576, 2013.

[27] Y. Niwa, Y. Hiura, H. Sawamura, and N. Iwai, "Inhalation exposure to carbon black induces inflammatory response in rats," Circulation Journal, vol. 72, no. 1, pp. 144-149, 2008.

[28] A. R. Huber, S. Kunkel, R. Todd III, and S. Weiss, "Regulation of transendothelial neutrophil migration by endogenous interleukin-8," Science, vol. 254, no. 5028, pp. 99-102, 1991.

[29] Y.-M. Kim, W. Reed, A. G. Lenz et al., "Ultrafine carbon particles induce interleukin-8 gene transcription and p38 MAPK activation in normal human bronchial epithelial cells," American Journal of Physiology - Lung Cellular and Molecular Physiology, vol. 288, no. 3, pp. L432-L441, 2005.

[30] A. Diaz, K. P. Chepenik, J. H. Korn, A. M. Reginato, and S. A. Jimenez, "Differential regulation of cyclooxygenases 1 and 2 by interleukin- $1 \beta$, tumor necrosis factor- $\alpha$, and transforming growth factor- $\beta 1$ in human lung fibroblasts," Experimental Cell Research, vol. 241, no. 1, pp. 222-229, 1998.

[31] M. C. Reddy, J. Subhashini, S. V. K. Mahipal et al., "C-Phycocyanin, a selective cyclooxygenase- 2 inhibitor, induces apoptosis in lipopolysaccharide-stimulated RAW 264.7 macrophages," Biochemical and Biophysical Research Communications, vol. 304, no. 2, pp. 385-392, 2003.
[32] J. Ferin, G. Oberdörster, and D. P. Penney, "Pulmonary retention of ultrafine and fine particles in rats," American Journal of Respiratory Cell and Molecular Biology, vol. 6, no. 5, pp. 535542, 1992.

[33] X. Y. Li, D. Brown, S. Smith, W. MacNee, and K. Donaldson, "Short-term inflammatory responses following intratracheal instillation of fine and ultrafine carbon black in rats," Inhalation Toxicology, vol. 11, no. 8, pp. 709-731, 1999.

[34] H. J. Bunn, D. Dinsdale, T. Smith, and J. Grigg, "Ultrafine particles in alveolar macrophages from normal children," Thorax, vol. 56, no. 12, pp. 932-934, 2001.

[35] J. R. Evans, A. E. Helmy, A. Cluroe, and A. D. Purushotham, "Lymphoma of the breast-case report and review of the literature," Journal of the Balkan Union of Oncology, vol. 9, no. 3, pp. 307-311, 2004. 


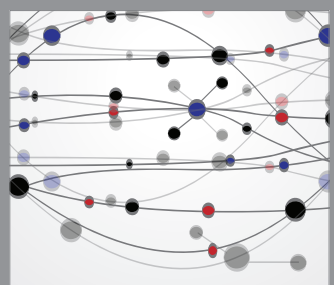

The Scientific World Journal
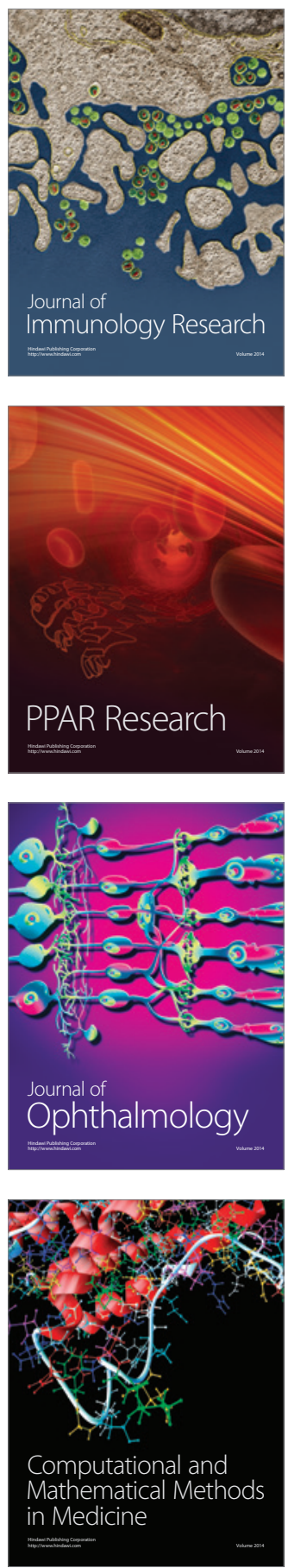

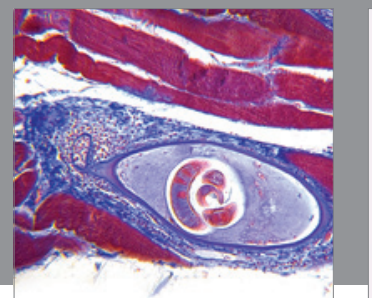

Gastroenterology

Research and Practice
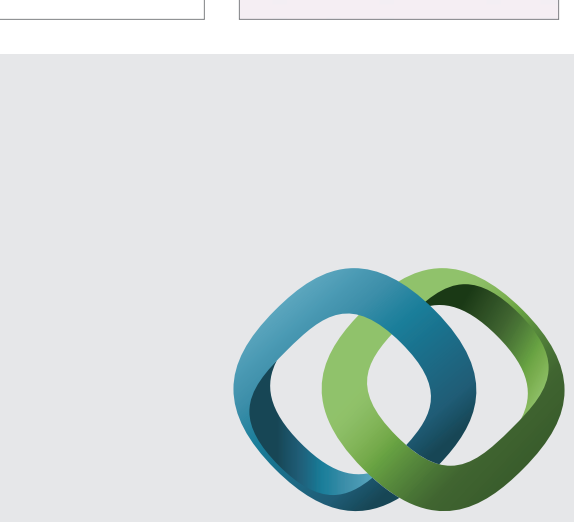

\section{Hindawi}

Submit your manuscripts at

http://www.hindawi.com
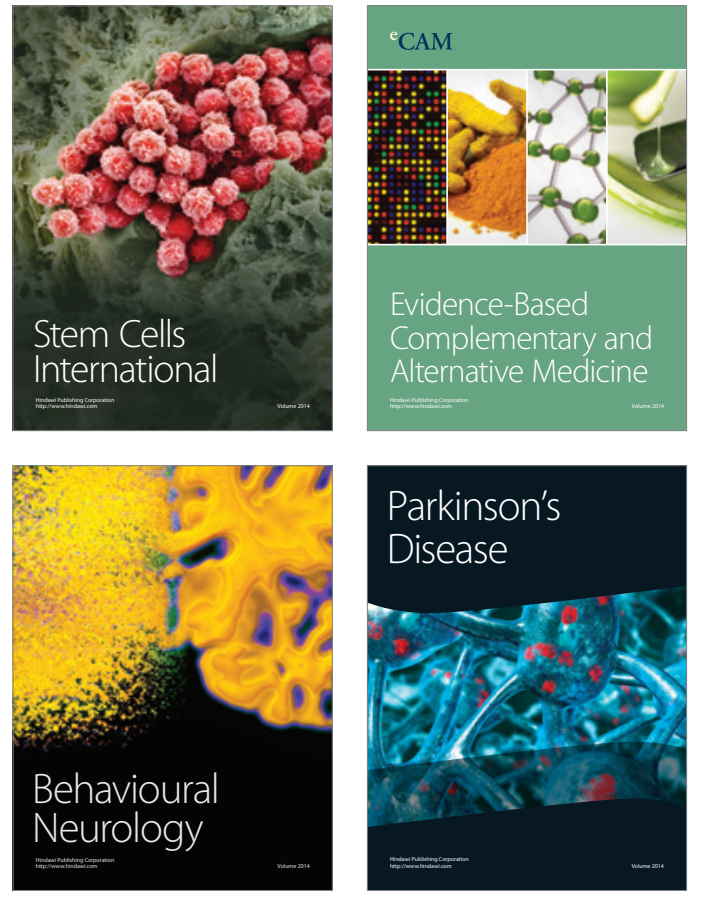
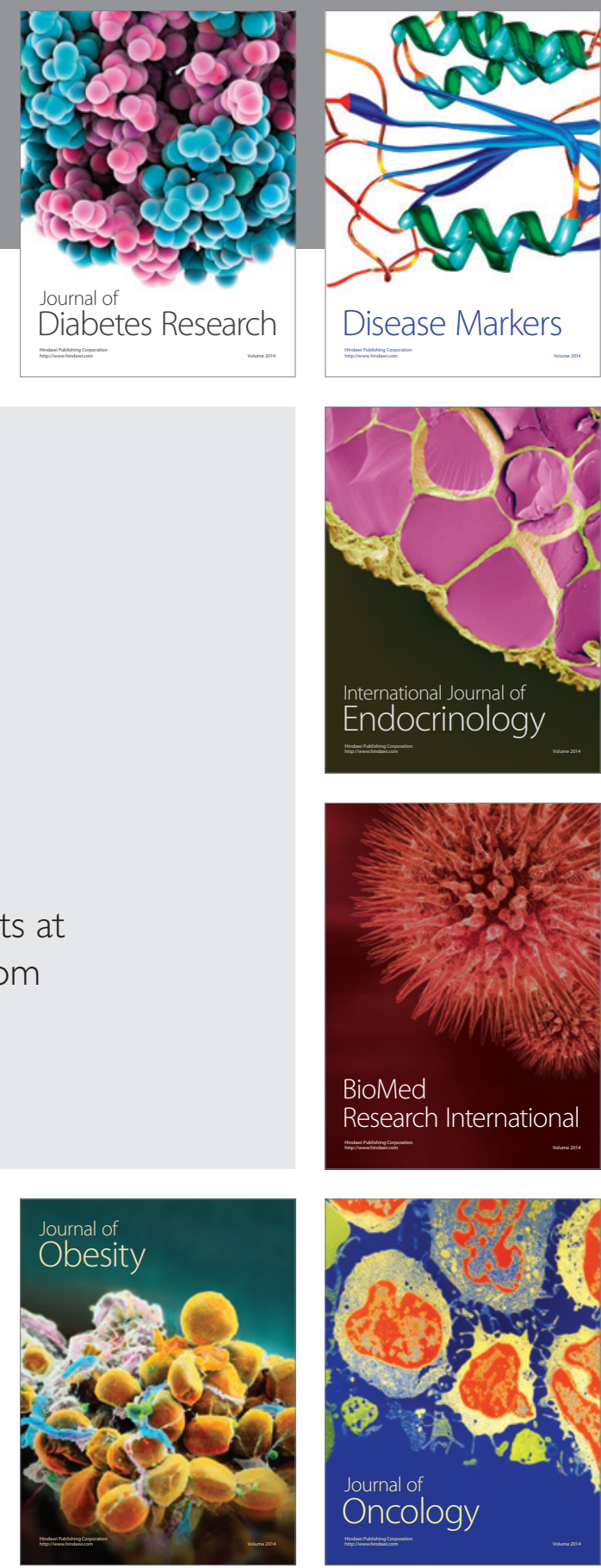

Disease Markers
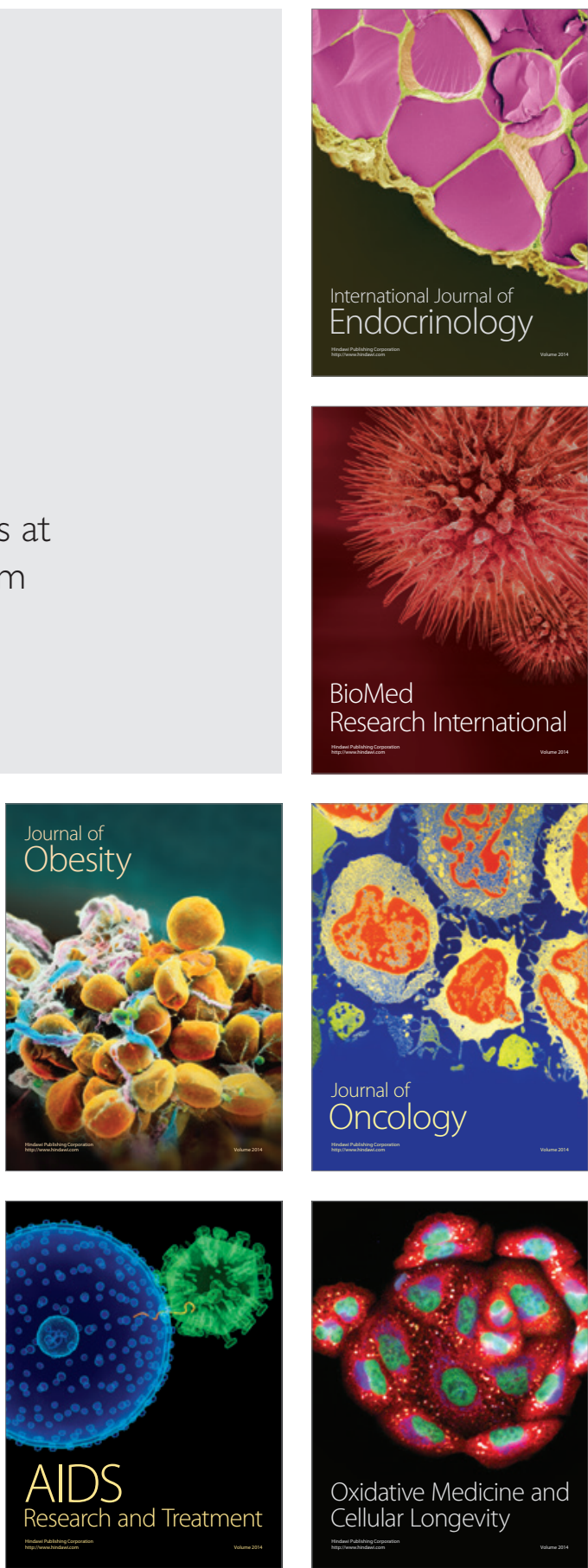